\title{
Innovative environment in the country and its importance in terms of business innovation as a precondition for the financial performance of company
}

\author{
Roman Juris ${ }^{1, *}$ and Aneta Cugova ${ }^{2}$ \\ ${ }^{1}$ University of Zilina, The Faculty of Operation and Economics of Transport and Communications, \\ Department of Economics, Univerzitna 1, 01026 Zilina, Slovakia \\ ${ }^{2}$ University of Zilina, The Faculty of Operation and Economics of Transport and Communications, \\ Department of Economics, Univerzitna 1, 01026 Zilina, Slovakia
}

\begin{abstract}
In today's world of significant progress and deepening globalization, both the private and the public sectors are forced to respond to the ever-changing competitive environment and incoming changes. It should therefore be in the interest of every government to prepare the country's innovation environment at the highest possible level and thus prepare innovative inputs for the private sector. In fact, businesses are the driving force for innovation, as they can keep pace with competitors, both in domestic and foreign markets. Addressing the issue of innovative landscape in the country and its importance in terms of business innovation is and will continue to be crucial in the future as innovation is one of the major factors of sustainability and improving the performance of the state's economy. The global economy is undergoing many changes with the increasing globalization bringing these changes. In a given situation of constant economic changes, it is inconceivable for the Slovak Republic to be successful without the substantial use of innovation. Today and with the greatest expectation in the future, modern economy will need to be based on a knowledge-based, open and innovative society. As such, the public sector should be able to prepare an appropriate innovation environment in the country and deliver innovative innovation inputs. Both the environment and inputs form the basis for the main focus of market economy innovation, represented by businesses. It is they who, through their internal processes, capture and generate ideas and transform them into innovative products or services.
\end{abstract}

\section{Introduction}

At the beginning of the 21 st century, the world economy is undergoing many changes, these changes being brought about by increasing globalization. In a given situation of continuous economic change, it is unimaginable for the Slovak Republic to be successful without making a significant use of innovation. Today, and most likely in the future, the

* Corresponding author: roman.juris@ fpedas.uniza.sk 
modern economy will need to be based on a knowledge-based, open and innovative society. The role of the public sector is to respond to changes in society and to continuously provide quality public services addressing the new needs of private and legal persons. The public sector is thus under increasing pressure to innovate and improve public administration and services. Universities and public research institutions play an important role in the innovation process. As a tool of the public sector, they include a wide range of entities whose purpose is to train, create and disseminate knowledge, or to develop new instrumentation, all with the main objective of storing and transferring knowledge. The public sector as such should be able to prepare a suitable innovation environment in the country and deliver quality innovation inputs. The environment as well as inputs are the basis for the main focus of market economy innovations, which represent enterprises. It is they who, through their internal processes, capture and generate ideas and turn them into innovative products and services, which is also reflected in the financial performance of the business.

\section{2 innovation and barriers to innovation}

This term was introduced into economics by Austrian economist Alois Schumpeter. He defined innovation as the imposition of a new combination of factors of production. Innovation is the driving force showing ambitious long-term goals for businesses. It also leads to the restoration of industrial structures and encourages the emergence of new economic activities [1] or any change in the internal structure of the production organism, but also of another system [2].

Innovation activity is a key factor in the success of a business, because if an organization does not want to lose its competitive ability, it must constantly innovate its products, even if there are apparently no reasons for doing so. If they fall asleep at the time of success, they will quickly lose the advantage [3].

Innovations cover a wide range of business activities, the most common classification of innovations is given in the following table.

Table 1. Breakdown of innovations.

\begin{tabular}{|c|c|c|}
\hline technological innovations & product innovation & process innovation \\
\hline $\begin{array}{c}\text { non-technological } \\
\text { innovations }\end{array}$ & organizational innovation & marketing innovations \\
\hline
\end{tabular}

Changes in industry, especially those in technological development and their application in production processes, subsequently products and services, can be referred to as innovations. The core elements of industrial innovation are basic knowledge, know-how and ideas that are subsequently transformed into new products, processes and services. We also consider the high speed of implementation of ideas to market conditions as an essential element of industrial innovation [4].

Based on a number of definitions, Kovac et al. [5] takes the view that the current concept of innovation shows that innovation is a key term for entrepreneurs or entrepreneurs. for the manager. It emphasizes the global concept of the concept as a philosophy of activity, which affects all components of the reproductive process (marketing, product and technology development, planning, production, sales, personnel training, management, etc.), but also social and environmental factors. The term innovation is understood as synonymous with successful production, assimilation and use of novelty in the economic and social spheres. 


\subsection{Technological innovations}

Technological innovations include new products and processes, but also significant technological changes to products and processes.

Product innovation is the introduction of goods or services that are new or significantly improved in terms of their characteristics or their intended use. This includes significant improvements in technical specifications, components and materials, software or other performance characteristics. Product innovations can use new knowledge or technology, or be built on new uses or combinations of existing knowledge or technology. The term product is used to cover goods and services. Product innovations include both the introduction of new goods and services as well as significant improvements in the functional or user characteristics of emerging goods and services [6].

Process innovation includes new or substantially improved manufacturing methods, distribution system, technology, equipment, procedures or software.

Both types of innovation require a relatively large expense, especially for the procurement of machinery, software and other production equipment. The dynamics of the economy's development lies in its diversity and reflects sectoral developments and international dependencies. The 2008 recession has had a prolonged and varying effect both across and within countries [7].

\subsection{Non-technological innovations}

Organizational innovation is a change in the structure of the company. It includes changes in managerial or organizational methods in relation to work and work organization, job organization and changes in the organization of external relations. The goal of organizational innovation is to accelerate the response to the identified needs of the customer.

Marketing innovation is the introduction of new or significantly improved product (packaging) design or sales methods to increase the attractiveness of products and services or to enter new markets. These innovations include significant changes in the way products and services are traded, including design and packaging changes. We cannot talk about marketing innovations in case of routine and seasonal changes (e.g. fashion changes of clothes), advertising or advertising, unless it is the first-time advertising or advertising based on the use of modern media [8].

These innovations are based on the knowledge and experience of competent managers. They aim to increase supply flexibility as well as increase the volume of products sold.

\section{Barriers to innovation}

Despite the potential and dynamism of small and medium-sized enterprises, they have not yet taken their place in the developed economies. The decline in cross-border lending led to a deterioration in the borrowing conditions of small firms [9]. There are many barriers to business development and innovation. On the other hand, we have confirmed our expectation about the bankruptcy prediction ability of index IN05, that is proven to be superior to Ohlson and Altman model and so is the most appropriate model for Slovak business environment [10]. Innovative SMEs may implement differentiation and focus strategies and survive without CSs, whereas innovation may be obtained through cost leadership strategy [11].

\subsection{Internal barriers}

Removing internal barriers is the task of the businesses themselves. 


\section{Absence of business development strategy}

Many SMEs lack strategic and planned management. They underestimate market research, which offers them information about competitors and potential customers, as well as a SWOT analysis, which is an effective aid in planning the company's future development. Instead, they prefer intuitive and operational decision-making without considering the negative consequences of such decisions. Instead of reacting in advance, it can only passively accept the consequences if unwanted situations arise. These findings are relevant for SME policies aimed at facilitating access to credit, reducing the cost of borrowing, and decreasing default; risk management of banks; and the application of theories of financial economics in the context of a financial crisis [12].

\section{Lack of managerial skills and knowledge}

The fact that many entrepreneurs lack experience in organizing, managing, creating a corporate culture, controlling strategic decision-making and communicating with foreign partners is negatively reflected in practice. They also lack a lot of economic and legal knowledge, especially often changing legislation is difficult to understand for such entrepreneurs.

\section{Lack of capital}

The lack of capital is due to the lack of own deposits, but also to the difficulty of obtaining foreign funds because they are not able to guarantee their repayment. The loan source is very expensive, which puts at risk the regular repayment of principal and high interest. Lack of capital causes small and medium-sized enterprises to lag behind with stateof-the-art technology and technology and thus a lower ability to compete in domestic and foreign markets. Every corporation has an economic and moral responsibility to its stockholders to perform well financially. However, the number of bankruptcies in Slovakia has been growing for several years without an apparent macroeconomic cause. To prevent a rapid denigration and to prevent the outflow of foreign capital, various efforts are being zealously implemented [13].

\section{Unrealistic ideas about the need for investment and operational resources}

Unrealistic ideas about the amount of investment funds for business development and unrealistic ideas about the amount of investment benefits often lead to undercapitalization of investment projects, prolonged investment construction and jeopardize the return on investment. In the normal course of business, the problem is the lack of cash needed to cover liabilities. The need to secure the cash flow for the day-to-day business leads entrepreneurs to operational management and diverts their attention from the prospective solution of tasks. Slovak entrepreneurs gave the economic factors a higher rating than Czech entrepreneurs. Similarly, Slovak entrepreneurs rated the importance of the Central Bank in establishing a stable business environment and the role of commercial banks in financing business needs more positively [14].

Freight equipment of the enterprise

Many entrepreneurs are too costly to start their business, but are investing more in exterior, interior, expensive cars than in business content, which would usually result in the company being equipped with high-quality technology and equipment and equipping workers with work equipment, protective equipment, and information. Also, entrepreneurs prefer short-term investment rather than creating long-term savings and deferred investment in larger development projects, especially for fear of currency depreciation.

\section{Insufficient capacity utilization}

Lack of information on competitors and customers results in oversized production capacity. Another reason may be to offer uninteresting products. The economic consequence is the cost increase as well as the underutilisation of fixed costs. 


\section{Conclusion}

Businesses do not have an impact on the removal of external barriers, but we believe that they are able to mitigate these impacts by their activity. We would propose to eliminate the reduced purchasing power of the population and the barriers that arise in a sectoral environment by investing in advertising and marketing (especially market research), as SMEs often save on marketing, which reduces consumers' awareness of the products they produce. customer unfavourable situation. Of course, it is problematic to invest in advertising and marketing if businesses do not have enough of their own resources. A risky way is to use foreign resources that will bring customers, but there is always the possibility of success in reconciling to low demand and stagnation. Further analyses show that the weak relationship between large banks and SMEs is a major cause for this phenomenon (Ogura, 2018). Interestingly, the financial crisis does not impact the performance of Italian gambling SMEs and some business segments, such as bingo, perform even better during the crisis [15].

Within the internal barriers we have identified mainly the unwillingness of management to engage in long-term investments in uncertain economic situations, especially in the area of technology. It should be noted, however, that while we have been waiting for a longer return on investment, these investments have a long-term impact on increasing labor productivity, increasing machine performance, increasing production capacity utilization. At the same time, however, we must consider whether the production produced will achieve the desired sales. Increasing sales can be ensured by expanding into foreign markets if the foreign market has potential for our products. Another internal barrier is the entrepreneurs themselves. In the centrally managed economies, the consequences were borne by the state as a whole, in market economies, they concern directly all the entities entering into the relationship with the given business entity. In other words, market participants (owners, creditors, suppliers, subscribers, employees, competitors, the state, etc.) [16]. The lack of strategic planning occurs especially in small and medium-sized enterprises. Entrepreneurs plan intuitively and react late to market changes because they did not anticipate them. At the same time, besides strategic planning, it is important to focus on general managerial knowledge in addition to knowledge and skills. The wave of global financial crises (20082009) caused a surge in the capital flows of developed countries particularly, between developed and developing countries. The crunch hit all financial sectors with unanticipated severity [17]. Entrepreneurs should pay particular attention to the management of human resources, which are the most important success factor, both in production and in the business itself.

The paper is an output of the science project VEGA 1/0428/17 CREATION OF NEW PARADIGMS OF FINANCIAL MANAGEMENT AT THE THRESHOLD OF THE $21^{\text {ST }}$ CENTURY IN CONDITIONS OF THE SLOVAK REPUBLIC.

\section{References}

1. European Commission, Green paper on innovation. (1995)

2. S. Vyparina, Inovacie pre podnikatelov. (2000)

3. L. Lesakova, Metody hodnotenia vykonnosti malych a strednych podnikov. (2004)

4. Transparency International, Index vnimania korupcie. (2009)

5. Euroekonom, Makroprostredie podniku. (2013)

6. L. Leasakova, Inovativny manazment vo vedomostnej ekonomike. (2008) 
7. A. Kitsos, P. Bishop, Economic resilience in Great Britain: the crisis impact and its determining factors for local authority districts. Annals of regional science 60, (2018)

8. E. Spisiakova, Typy inovacii a ich zavadzania v podnikoch SR. (2008)

9. F. Bremus, K. Neugebauer, Reduced cross-border lending and financing costs of SMEs. Journal of International Money and Finance 80, (2018)

10. B. Gavurova, M. Packova, M. Misankova, L. Smrcka, Predictive potential and risks of selected bankruptcy prediction models in the Slovak business environment. Journal of Business Economics and Management 18, 6 (2017)

11. S. Ulubeyli, A. Kazaz, S. Sahin, Survival of construction SMEs in macroeconomic crises Innovation-based competitive strategies. Journal of Engineering Design and Technology 16, (2018)

12. F. D. Duarte, A. P. M. Gama, M. A. Gulamhussen, Defaults in bank loans to SMEs during the financial crisis. Small Business Economics 51, (2018)

13. T. Kliestik, M. Misankova, K. Valaskova, L. Svabova, Bankruptcy prevention: new effort to reflect on legal and social changes. Science and Engineering Ethics 24, 2 (2018)

14. M. Cepel, A. Stasiukynas, A. Kotaskova, J. Dvorsky, Business Environment Quality Index in the SME Segment. Journal of Competitiveness 10, 1, (2018)

15. F. La Rosa, F. Bernini, Corporate governance and performance of Italian gambling SMEs during recession. International Journal of Contemporary Hospitality Management 30, (2018)

16. T. Kliestik, J. Majerova, Selected issues of selection of significant variables in the prediction models. Financial management of firms and financial institutions 10, (2015)

17. F. Mustafa, A. Khursheed, M. Fatima, Impact of global financial crunch on financially innovative microfinance institutions in South Asia. Financial Innovation 4, (2018) 